\title{
ANALISIS TRIWULANAN: \\ Perkembangan Moneter, Perbankan dan Sistem Pembayaran, Triwulan III - 2011
}

\author{
Tim Penulis Laporan Triwulanan, Bank Indonesia
}

Rapat Dewan Gubernur (RDG) Bank Indonesia pada tanggal 11 Oktober 2011 memutuskan untuk menurunkan BI Rate sebesar 25 bps menjadi 6,50\%. Bank Indonesia juga akan tetap menempuh langkah-langkah stabilisasi nilai tukar rupiah khususnya dari dampak gejolak pasar keuangan global. Keputusan ini diambil sejalan dengan keyakinan Bank Indonesia bahwa inflasi pada akhir tahun ini maupun tahun depan akan berada di bawah 5\%. Selain itu, langkah-langkah tersebut ditempuh sebagai antisipasi untuk memitigasi dampak penurunan kinerja ekonomi dan keuangan global terhadap kinerja perekonomian Indonesia. Ke depan, Dewan Gubernur akan terus mencermati perkembangan ekonomi dan keuangan global serta menempuh respons suku bunga serta bauran kebijakan moneter dan makroprudensial lainnya untuk memitigasi potensi penurunan kinerja perekonomian Indonesia tersebut dengan tetap mengutamakan pencapaian sasaran inflasi, yaitu 5\% $1 \%$ pada tahun 2011 dan 4,5\% 1\% pada tahun 2012 .

Dewan Gubernur terus mewaspadai tingginya risiko dan ketidakpastian di pasar keuangan global serta kecenderungan menurunnya kinerja perekonomian global akibat permasalahan utang dan fiskal di Eropa dan AS. Perhatian terutama ditujukan pada dampak jangka pendek melalui jalur finansial berupa melemahnya bursa saham, meningkatnya indikator risiko utang, dan tekanan pembalikan arus modal portofolio (capital reversals) oleh investor global dari emerging economies, termasuk Indonesia. Sementara itu, kinerja perekonomian global terindikasi melemah seperti tercermin pada perlambatan kegiatan produksi dan penjualan ritel yang disertai dengan tingkat keyakinan konsumen yang melemah di negara maju dan koreksi sejumlah harga komoditas internasional. Di sisi lain, tekanan inflasi mulai mereda, meski inflasi negara emerging markets masih relatif tinggi sehingga terjadi pergeseran respons kebijakan moneter ke arah netral atau akomodatif. Ke depan, secara keseluruhan Dewan Gubernur melihat kecenderungan menurunnya pertumbuhan ekonomi negara maju, melambatnya volume perdagangan dunia, dan menurunnya harga komoditas global. Sementara itu di sektor keuangan, tingginya ekses likuiditas global dan persespi resiko investor masih akan mendorong tetap 
derasnya aliran modal asing masuk ke negara-negara emerging economies, termasuk Indonesia, baik dalam bentuk PMA maupun investasi portofolio.

Dewan Gubernur menilai bahwa fundamental ekonomi dan perbankan nasional tetap kuat di tengah meningkatnya kekhawatiran terhadap prospek ekonomi dunia. Pertumbuhan ekonomi pada triwulan IV 2011 diperkirakan akan lebih tinggi, terutama didukung oleh konsumsi dan kegiatan investasi sehingga secara keseluruhan tahun 2011 dapat mencapai 6,6\%. Sejauh ini, dampak gejolak ekonomi global lebih dirasakan di pasar keuangan, sementara sektor riil relatif belum terpengaruh. Namun, perekonomian global yang melemah diperkirakan akan memengaruhi kinerja ekonomi domestik pada tahun 2012, baik melalui dampaknya pada pasar keuangan maupun terhadap kegiatan perdagangan internasional. Pertumbuhan ekonomi domestik tahun 2012 diprakirakan berada di sekitar 6,2\%-6,7\%. Pertumbuhan tersebut ditopang oleh konsumsi yang tetap kuat dan investasi yang meningkat, namun ekspor akan menghadapi tekanan. Secara sektoral, seluruh sektor ekonomi diprakirakan akan tumbuh dengan baik. Sektor-sektor yang diprakirakan menjadi pendorong utama pertumbuhan ekonomi ke depan, antara lain sektor industri; sektor perdagangan, hotel dan restoran; dan sektor transportasi dan komunikasi.

Neraca Pembayaran Indonesia (NPI) pada triwulan IV 2011 diprakirakan akan kembali surplus setelah mengalami tekanan akibat terjadinya aliran modal keluar pada triwulan sebelumnya. Secara keseluruhan tahun 2011, NPI diprakirakan akan tetap mencatat surplus yang cukup besar. Surplus NPI ini diprakirakan akan tetap berlangsung pada tahun 2012 terutama didukung oleh surplus transaksi modal dan finansial yang terus meningkat, baik dalam bentuk investasi portofolio maupun investasi langsung. Sejalan dengan itu, cadangan devisa pada akhir September 2011 tercatat sebesar 114,5 miliar dolar AS, atau setara dengan 6,5 bulan impor dan pembayaran utang luar negeri Pemerintah. Jumlah cadangan devisa tersebut lebih dari cukup untuk mendukung kestabilan nilai tukar rupiah.

Nilai tukar rupiah pada triwulan III 2011 mengalami tekanan, khususnya pada bulan September 2011. Pada triwulan III 2011, nilai tukar rupiah melemah 2,42\% (ptp) menjadi Rp8.790 per dolar AS dengan volatilitas yang meningkat. Namun, pelemahan nilai tukar rupiah tersebut masih sejalan dengan pergerakan nilai tukar mata uang negara kawasan. Tekanan terhadap rupiah antara lain dipengaruhi oleh meningkatnya faktor risiko global akibat kekhawatiran terhadap prospek ekonomi dunia. Selain itu, meningkatnya permintaan valas untuk memenuhi pembayaran impor turut menekan nilai tukar rupiah. Ke depan, Bank Indonesia akan terus menjaga stabilitas nilai tukar rupiah guna mendukung terpeliharanya kestabilan makroekonomi. 
Tekanan inflasi terus menurun. Inflasi IHK pada triwulan III 2011 tercatat sebesar 1,89\% (qtq) atau 4,61\% (yoy), lebih rendah dari periode yang sama tahun sebelumnya. Penurunan tekanan inflasi ini berasal dari kelompok volatile food dan administered prices seiring dengan membaiknya pasokan, turunnya harga komoditas pangan internasional dan minimalnya kebijakan Pemerintah terkait harga komoditas strategis. Sementara itu, tekanan kelompok inti di luar kenaikan harga emas juga relatif terjaga baik karena kebijakan apresiasi nilai tukar pada periode sebelumnya dan masih cukup memadainya pasokan dalam merespons permintaan. Dengan perkembangan tersebut, inflasi pada tahun 2011 diyakini akan lebih rendah dari 5\%. Tahun 2012, inflasi akan tetap terkendali dan diprakirakan di bawah 5\% seiring dengan terjadinya koreksi harga komoditas global dan melemahnya perekonomian dunia.

Stabilitas sistem perbankan tetap terjaga dengan fungsi intermediasi yang membaik meskipun terjadi gejolak pasar keuangan akibat pengaruh global. Stabilitas industri perbankan masih tetap terjaga dengan baik sebagaimana tercermin pada tingginya rasio kecukupan modal (CAR/Capital Adequacy Ratio) yang berada jauh di atas minimum 8\% dan rendahnya rasio kredit bermasalah (NPL/Non Performing Loan) gross di bawah 5\%. Sementara itu, penyaluran kredit untuk pembiayaan kegiatan perekonomian terus berlanjut, tercermin pada pertumbuhan kredit yang mencapai 23,8\% (yoy) hingga akhir September 2011. Bank Indonesia terus berupaya menjaga stabilitas sistem perbankan dan mendorong fungsi intermediasi dengan tetap memperhatikan prinsip kehati-hatian dengan mendorong ke arah pertumbuhan kredit produktif sehingga perekonomian nasional tetap dapat mencapai pertumbuhan yang optimal di tengah kondisi perekonomian global yang masih diliputi ketidakpastian.

Kehandalan dan efisiensi sistem pembayaran turut membantu capaian kinerja makroekonomi Indonesia. Dukungan sistem pembayaran terhadap kinerja perekonomian Indonesia terlihat dari ketersediaan Sistem Bank Indonesia-Real Time Gross Settlement (BIRTGS), Bank Indonesia-Scripless Security Settlement System (BI-SSSS) serta Sistem Kliring Nasional Bank Indonesia (SKNBI) yang mencapai 100\%. Selain itu, kehandalan sistem pemrosesan Alat Pembayaran Menggunakan Kartu (APMK) dan Uang Elektronik yang diselenggarakan oleh pihak di luar Bank Indonesia juga tetap terjaga. Bank Indonesia juga tetap mampu memenuhi kebutuhan uang kartal meskipun terdapat kenaikan permintaan uang kartal oleh masyarakat secara signifikan selama Ramadhan dan libur Idul Fitri yang lalu. 
112 Buletin Ekonomi, Moneter dan Perbankan, Oktober 2011

halaman ini sengaja dikosongkan 